\title{
A FIELD STUDY OF OXYGEN CONSUMPTION AND ESTIMATED ENERGY EXPENDITURE IN THE EXERCISING HORSE
}

\author{
J. HANÁK, P. JAHN, R. KABEŠ, M. SEDLINSKÁ, Z. ŽERT, \\ J. MEZEROVÁ, O. CHVÁTAL \\ Equine Clinic, Faculty of Veterinary Medicine, University of Veterinary and Pharmaceutical Sciences, \\ Brno, Czech Republic
}

Received August 30, 2000

Accepted May 28, 2001

Abstract

Hanák J., P. Jahn, R. Kabeš, M. Sedlinská, Z. Žert, J. Mezerová, O. Chvátal: A Field Study of Oxygen Consumption and Estimated Energy Expenditure in the Exercising Horse. Acta Vet. Brno 2001, 70: 133-139.

The major goal of this study was to estimate the aerobic and anaerobic contribution to energy expenditure in the running warmblood horse under field conditions. The oxygen consumption $\left(\mathrm{VO}_{2}\right)$ in 12 saddle horses was determined at rest, walk, trot, and canter and in 6 horses at gallop. In the 10 min immediately following exercise the relative oxygen debt $\left(\mathrm{RD}-\mathrm{VO}_{2}\right)$ was measured. The horses were exercised by riders in the various gaits at speeds representing 15, 30, 50 and $70 \%$ of the their individual maximum speed $\left(\mathrm{V}_{\mathrm{max}}\right)$. The distances covered were $3000 \mathrm{~m}$ in each walk, trot and canter and $1500 \mathrm{~m}$ in gallop. $\mathrm{VO}_{2}$ and $\mathrm{RD}-\mathrm{VO}_{2} \mathrm{~m}$ and energy expenditure (J.kg.min ${ }^{-1}$ ) using the oxygen caloric equivalent of the measured respiratory quotient (RQ) were studied for possible relations to the speed. The proportion of anaerobic energy expenditure (\%E anaer.) to the total energy production was also investigated. A linear relation between speed and aerobic energy expenditure (E) and a quadratic relation between speed and anaerobic energy expenditure (RD-E) and total energy expenditure (TE) was found. The $\% \mathrm{E}$ anaer. was $1.21 \pm 0.40$ at a speed of $15 \%$ $\mathrm{V}_{\mathrm{max}}, 3.40 \pm 0.38$ at $30 \% \mathrm{~V}_{\text {max }}, 18.58 \pm 2.05$ at $50 \% \mathrm{~V}_{\text {max }}$, and $29.47 \pm 1.17$ at $70 \% \mathrm{~V}_{\text {max }}$.

Post-exercise oxygen uptake appears a suitable measure for the major part of the oxygen debt (relative oxygen debt) and could be considered as an indicator of anaerobically released energy. For this reason it may also be an indicator of the anaerobic capacity of the horse at a standard or maximal exercise.

Horse, exercise, oxygen uptake, oxygen debt, energy consumption, anaerobic energy

In recent years, a considerable amount of research has been performed in an attempt to describe the physiological response of the horse to exercise and training. Mostly the changes in cardiorespiratory functions during different intensities of exercise have been studied extensively and reported for various breeds of horses. It has been suggested that heart rate and oxygen consumption $\left(\mathrm{VO}_{2}\right)$, measured at sub-maximal exercise, are useful in assessing cardiovascular fitness in the horse. Calculated parameters such as the speed at a heart rate of 200 beats. $\mathrm{min}^{-1}(\mathrm{~V}-200)$ and oxygen consumption at a heart rate of 200 beats. $\mathrm{min}^{-1}\left(\mathrm{VO}_{2}-200\right)$ are considered as highly useful (Perss on 1983; Perss on et al. 1983; Rose et al. 1990). Other suitable indices of fitness have included the velocity (V) and heart rate (HR) at a blood lactate concentration of 4 mmol. $^{-1}$ i.e. $\mathrm{VLa}_{4}$ and $\mathrm{HR}_{4}$, respectively (Rose et al. 1990; Harkins et al. 1993; Poso et al. 1993; Castejon et al. 1994; Misumi et al. 1994; Gotlieb-Vedi et al. 1995; Persson 1997; Munoz et al. 1997; Eaton et al. 1999 and others).

While sub-maximal indices have been commonly used to predict the maximum working capacity, there are relatively few studies in which the cardiorespiratory measurements have been performed during maximal exercise or in which energy expenditure and heat production have been calculated from oxygen uptake and post exercise oxygen debt (Karlsen and Nadaljak 1972; Rose et al. 1988; Eaton et al. 1995).

Address for correspondence:

Prof. MVDr. Jaroslav Hanák, DrSc.

Equine Clinic

Palackéty of $1-3,612$ etring and Pharmaceutical Sciences

Palackého 1-3, 61242 Brno, Czech Republic
Phone: $x$ 420-5-4156 2373

Fax: $x$ 420-5-4156 2395

http://www.vfu.cz/acta-vet/actavet.htm 
The major goal of this study was to estimate the aerobic and anaerobic contribution to energy expenditure in the running warmblood horse under field conditions as criteria for performance and fitness. The workload of the horses at walk, trot, canter and gallop was standardised and expressed as a percentage of the individual maximum generated speed over $400 \mathrm{~m}$. The energy expenditure for each gait was calculated from oxygen uptake during and after each bout of exercise.

\section{Materials and Methods}

Twelve healthy warmblood saddle horses ranging in age from 4 to 12 years and with a mean bodyweight of $477.5 \pm 32.8 \mathrm{~kg}$ were used in the experiment. The horses were ridden by riders weighing $70-80 \mathrm{~kg}$ and all were in the same stage of training.

On the first day of trial each horse's maximum speed $\left(\mathrm{V}_{\max }\right)$ was determined by galloping the horses over a distance of $400 \mathrm{~m} . \mathrm{V}_{\max }$ averaged $750 \pm 36 \mathrm{~m}_{\mathrm{min}} \mathrm{m}^{-1}$ (range $\left.705-810\right)$. On the following day all horses were exercised at the walk, trot and canter, at each gait over a distance of $3000 \mathrm{~m}$. The speeds set for the gaits were such that they corresponded to 15,30 and $50 \%$ of the horses individual $\mathrm{V}_{\max }$. On completion of each level of exertion, the horses were kept standing for $10 \mathrm{~min}$ for measurement of recovery oxygen consumption (relative oxygen debt). On the third day, six of the horses were subjected to a gallop over $1500 \mathrm{~m}$ at a speed corresponding to $70 \% \mathrm{~V}_{\max }$ Immediately after this exercise session, the recovery oxygen consumption was determined as on previous day. On all occasions each horse was exercised by its own rider. To ensure that the correct and constant speed was maintained, the riders were equipped with a transmitter and earphones to enable them to receive pacemaker signals from a magnetic tape that dictated the individual pace and headed them around an $800 \mathrm{~m}$ oval track. Poles placed at the inside of the track at each $50 \mathrm{~m}$ enabled the determination of the standard speed of each horse at each work load.

A radio-telemetric method (Hanák 1987) which utilised a two channel TELTEST Instrument (Chirana) was used to monitor heart rate (HR) on the first channel and the breathing frequency (RR) and tidal volume (VT) on the second one under resting, all exercise and recovery conditions. RR and VT were determined from recordings obtained by a semiconductor pressure transducer located in one of the openings of an air tight respiratory mask fitted to the horse. The response of this transducer was calibrated using an ETALON-NB 150 Instrument (Bergische Gasmesserfabrik). A linear response was obtained for flow rates up to $15001 . \mathrm{min}^{-1}$, corresponding to $0.4 \mathrm{kPa}$. Minute pulmonary ventilation (VE) was calculated as a product of RR and VT values and then corrected for BTPS conditions ("body temperature pressure saturated") using special tables. Rectal temperature was measured for this purpose.

Expired air samples were collected as aliquots of a very small fraction of the expired air via a plastic tube (internal diameter $5 \mathrm{~mm}$ ) connected to the respiratory mask. The tube led to a five-port collector equipped with five plastic bags, and controlled manually by the rider. Expired gas was collected from the horse with rider standing quietly for $10 \mathrm{~min}$ prior to exercise, throughout each exercise period and for $10 \mathrm{~min}$ after each exercise. One bag was used for each collection period. To avoid erroneous results due to gas exchange through the plastic bag wall, the atmospheric and expired gases were analysed on location, immediately following collection by the Scholander method and equipment. Values were corrected to tabulated STPD conditions ("standard temperature and pressure dry"). The oxygen consumption $\left(\mathrm{VO}_{2}\right)$, carbon dioxide production $\left(\mathrm{VCO}_{2}\right)$ and respiratory quotient $(\mathrm{RQ})$ for each workload were determined from the gas analyses (\% at inspired minus \% at expired gas) and pulmonary ventilation (VE). Furthermore the relative oxygen debt was calculated $\left(\mathrm{RD}-\mathrm{VO}_{2}\right)$ for each workload. RD- $\mathrm{VO}_{2}$ was represented by the mean oxygen consumption during the ten minutes after exercise minus the standing values obtained prior to exercise. The reproducibility of this method had been determined previously by collecting a total of 20 expired air samples into plastic bag from 5 horses that were exercised at sub-maximal steady state conditions.

The exercise energy expenditure (E) and the post exercise energy expenditure (RD-E) for each workload were calculated from the determined RQ values and their tabulated oxygen caloric equivalent. Total energy expenditure (TE) for each exercise was E plus RD-E. Percentage of energy generated by the anaerobic metabolism (\%E anaer.) was determined from the contribution of RD-E to TE.

The relationship between energy expenditure and speed was analysed in a linear and exponential regression model using routine statistical procedures.

\section{Results}

The mean $\pm \mathrm{SD}$ of values measured for respiratory and energy parameters at each workload are shown in Table 1. The linear or exponential for aerobic energy expenditure (E), anaerobic energy expenditure (RD-E), total energy expenditure (TE) and the contribution of anaerobically released energy (\%E anaer.) with the exercise speed (V) are given in Table 2. 
Table 1

Respiratory and energy expenditure parameters at rest and at four workloads (mean \pm S.E.M.)

\begin{tabular}{|l|c|c|c|c|c|}
\hline & Standing & Walk & Trot & Canter & Gallop \\
\hline$\% \mathrm{~V}_{\max }$ & 0 & 15 & 30 & 50 & 70 \\
\hline $\mathrm{n}$ & 12 & 12 & 12 & 12 & 6 \\
\hline Distance $(\mathrm{m})$ & - & 3000 & 3000 & 3000 & 1500 \\
\hline Time $(\mathrm{min})$ & 10 & $29.8 \pm 1.4$ & $11.8 \pm 0.7$ & $8.4 \pm 0.6$ & $2.8 \pm 0.1$ \\
\hline Speed $\left(\mathrm{m} \cdot \mathrm{min}^{-1}\right)$ & 0 & $103.3 \pm 4.4$ & $253.8 \pm 11.8$ & $358.3 \pm 14.9$ & $532.0 \pm 35.1$ \\
\hline $\begin{array}{l}\mathrm{VO}_{2} \\
\left(\mathrm{ml} \cdot \mathrm{kg}^{-1} \cdot \mathrm{min}^{-1}\right)\end{array}$ & $4.0 \pm 0.7$ & $22.3 \pm 1.6$ & $49.1 \pm 4.5$ & $83.2 \pm 9.2$ & $116.5 \pm 9.1$ \\
\hline $\mathrm{RQ}$ & $0.95 \pm 0.01$ & $0.78 \pm 0.01$ & $0.79 \pm 0.01$ & $0.90 \pm 0.01$ & $1.01 \pm 0.01$ \\
\hline $\begin{array}{l}\mathrm{RD}-\mathrm{VO} \\
\left(\mathrm{ml} . \mathrm{kg}^{-1} \cdot \mathrm{min}^{-1}\right)\end{array}$ & 0 & $0.23 \pm 0.06$ & $1.73 \pm 0.21$ & $18.73 \pm 1.77$ & $48.69 \pm 4.73$ \\
\hline $\mathrm{RD}-\mathrm{RQ}$ & - & $0.85 \pm 0.01$ & $0.94 \pm 0.03$ & $0.98 \pm 0.01$ & $1.02 \pm 0.01$ \\
\hline $\begin{array}{l}\mathrm{E} \\
\left(\mathrm{J} . \mathrm{kg}^{-1} \cdot \mathrm{min}^{-1}\right)\end{array}$ & $87.6 \pm 6.4$ & $438.4 \pm 31.7$ & $982.8 \pm 91.7$ & $1712.8 \pm 188.9$ & $2447.3 \pm 191.5$ \\
\hline $\begin{array}{l}\mathrm{RD}-\mathrm{E} \\
\left(\mathrm{J} . \mathrm{kg}^{-1} \cdot \mathrm{min}^{-1}\right)\end{array}$ & 0 & $4.7 \pm 1.2$ & $36.2 \pm 4.5$ & $393.4 \pm 37.4$ & $1022.7 \pm 99.5$ \\
\hline $\begin{array}{l}\mathrm{TE} \\
\left(\mathrm{J} . \mathrm{kg}^{-1} \cdot \mathrm{min}^{-1}\right)\end{array}$ & $87.6 \pm 6.4$ & $443.3 \pm 32.4$ & $1018.4 \pm 94.7$ & $2106.2 \pm 198.7$ & $3470.0 \pm 278.6$ \\
\hline$\% \mathrm{E} \mathrm{anaer}$ & 0 & $1.21 \pm 0.49$ & $3.40 \pm 0.38$ & $18.58 \pm 2.05$ & $29.47 \pm 1.17$ \\
\hline
\end{tabular}

Table 2

The Dependence of aerobic energy expenditure (E), anaerobic energy expenditure (RD-E), total energy expenditure (TE) and the contribution of anaerobically released energy (\%E anaer.) to the exercise speed (V).

\begin{tabular}{|l|c|c|c|c|c|}
\hline & Equation & $\mathrm{a}$ & $\mathrm{b}$ & $\mathrm{R}$ & $\mathrm{R}^{2}(\%)$ \\
\hline $\begin{array}{l}\mathrm{E} \\
\left(\mathrm{J} \cdot \mathrm{kg}^{-1} \cdot \mathrm{min}^{-1}\right)\end{array}$ & $\mathrm{Y}=\mathrm{a}+\mathrm{bV}$ & 12.3533 & 4.4709 & 0.98 & 95.47 \\
\hline $\begin{array}{l}\mathrm{RD}-\mathrm{E} \\
\left(\mathrm{J} . \mathrm{kg}^{-1} \cdot \mathrm{min}^{-1}\right)\end{array}$ & $\mathrm{Y}=\exp (\mathrm{a}+\mathrm{bV})$ & 0.3050 & 0.0137 & 0.96 & 92.00 \\
\hline $\begin{array}{l}\mathrm{TE} \\
\left(\mathrm{J} . \mathrm{kg}^{-1} \cdot \mathrm{min}^{-1}\right)\end{array}$ & $\mathrm{Y}=\exp (\mathrm{a}+\mathrm{bV})$ & 4.9620 & 7.0065 & 0.95 & 90.27 \\
\hline$\% \mathrm{E}$ anaer. & $\mathrm{Y}=\exp (\mathrm{a}+\mathrm{bV})$ & -0.6685 & 8.4490 & 0.94 & 88.08 \\
\hline
\end{tabular}

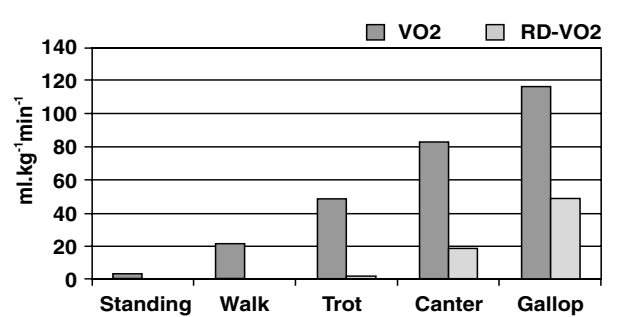

Fig. 1. The oxygen consumption $\left(\mathrm{VO}_{2}\right)$ and relative osygen debt $\left(\mathrm{RD}-\mathrm{VO}_{2}\right)$ at rest and four workloads.
The oxygen consumption and relative oxygen debt at each workload is demonstrated in Fig. 1. The linear relationship between aerobic energy consumption and speed is shown in Fig. 2. The relationship between speed and anaerobic energy expenditure, total energy consumption and percentage of anaerobic energy contribution are expressed by exponential functions (Fig. 3, 4, 5). 


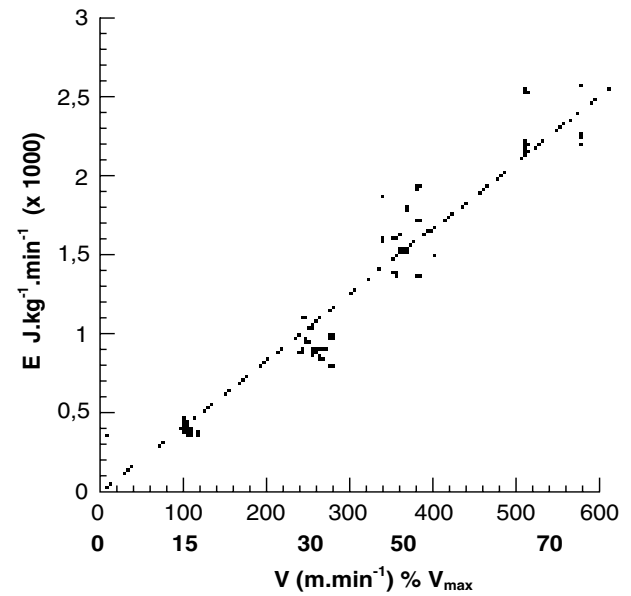

Fig. 2. The relationship between aerobic energy consumption (E) and speed (V) or $\% \mathrm{~V}_{\text {max }}$.

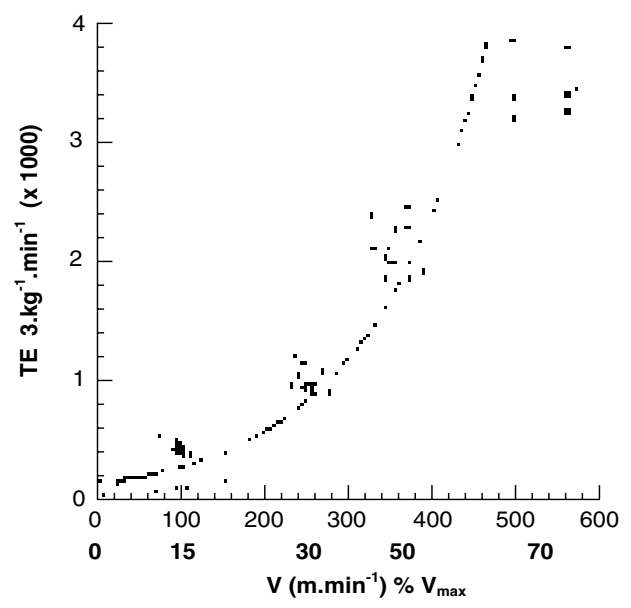

Fig. 4. The relationship between total energy consumption (TE) and speed (V) or $\% \mathrm{~V}_{\max }$.

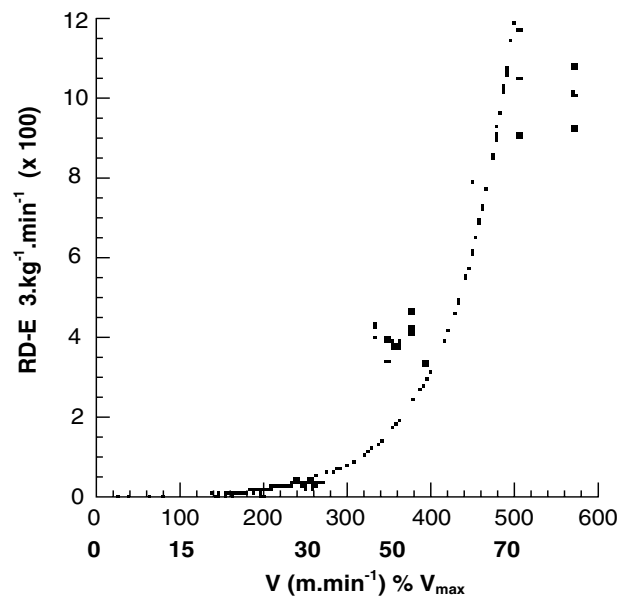

Fig. 3. The relationship between anaerobic energy expenditure (RD-E) and speed (V) or \% $\mathrm{V}_{\text {max }}$.

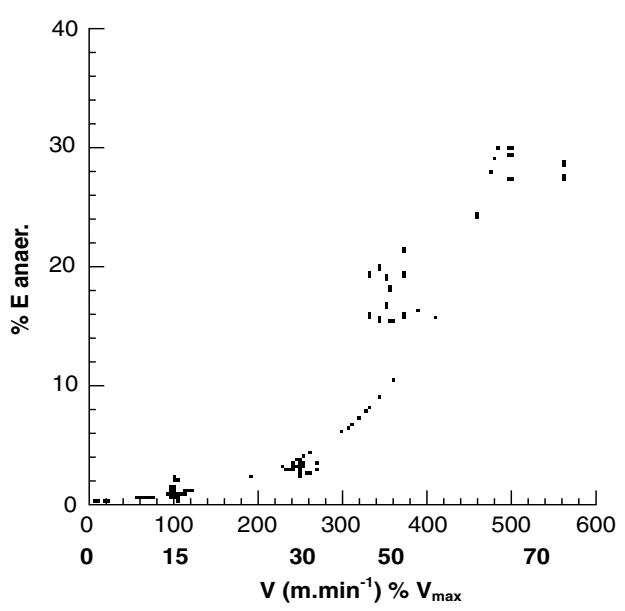

Fig. 5. The relationship between percentage of anaerobic energy contribution (\% E anaer.) and speed (V) or $\% \mathrm{~V}_{\text {max }}$.

\section{Discussion}

For practical purposes, the workloads in this study were expressed as percentage of maximum speed rather than in $\%$ of $\mathrm{VO}_{2}$ max or $\%$ of maximum heart rate. Training programmes currently applied in Czech Republic all are designed such that the proportion of maximum speed is used as benchmarks for intensity. It was therefore considered important to quantify the energy expenditure and relative demands on the aerobic and anaerobic components of metabolism under these circumstances.

The aerobic component of energy production can be readily calculated from the RQ values and $\mathrm{VO}_{2}$ during the exercise bout (Knuttigen 1970). However, the estimation of the anaerobic component is more difficult. In equine exercise physiology, blood 
lactate accumulation is used as an indicator of released anaerobic energy (Rose et al. 1990; Harkins et al. 1993; Poso et al. 1993; Castejon et al. 1994; Misumi et al. 1994; Gotlieb-Vedi et al. 1995; Persson 1997; Munoz et al. 1997; Eaton et al. 1999 and others). Post-exercise oxygen uptake $\left(\mathrm{RD}-\mathrm{VO}_{2}\right)$, which measures the oxygen debt, is considered to represent the anaerobic energy expenditure during exercise in humans and also appears valuable in the assessment of anaerobic capacity (Knuttigen 1970). For practical purposes, the contribution of anaerobically released energy during exercise, calculated from the oxygen debt could be utilised in the assessment of the total energy balance ( $\mathrm{VO}_{2}$ plus $\mathrm{RD}-\mathrm{VO}_{2}$, and $\mathrm{E}$ plus $\mathrm{RD}-\mathrm{E}$, respectively). The replenishment of the real oxygen debt, however, takes longer than $10 \mathrm{~min}$, possibly up to several hours (Astrand and Rodahl 1977). Due to design constraints, the oxygen uptake could only be measured for the first $10 \mathrm{~min}$ after each bout of exercise in the current study. Therefore the real oxygen debt could not be determined. The absolute oxygen debt and consequently the absolute energy expenditure therefore could be substantially higher than our measured values. However, the calculated values for $\mathrm{RD}-\mathrm{VO}_{2}, \mathrm{RD}-\mathrm{E}$ and $\% \mathrm{E}$ aner. appear the best approximation of the true values under field conditions. These parameters could be used in the practical evaluation of the horse's working capacity and the contribution of aerobic and anaerobic components to its performance or fitness. The oxygen debt as an expression of anaerobic metabolic processes significantly influences the total energy expenditure (TE), which is exponentially related to exercise intensity, i.e. velocity or $\% \mathrm{~V}_{\text {max }}$

The negligible contribution of anaerobic metabolism during continuous exercise at the walk $(1.2 \%)$ and trot $(3.4 \%)$ to the total energy expenditure could be considered as a pulmonary oxygen deficit. We suggest that this is the result of a slower adjustment of cardiorespiratory functions to the instantaneous saturation of working tissues with oxygen in the initial phase of each bout of exercise. Oxygen uptake is thus temporarily lower than the real consumption in the tissues. After some time the oxygen uptake reaches steady state level, depending on the intensity of exercise. At this point at exercise intensities of less than $30 \% \mathrm{~V}_{\max }$ (walk and trot), mainly aerobic metabolism is active.

At the exercise values above $30 \% \mathrm{~V}_{\max }$ (canter and gallop) the pulmonary oxygen deficit attains more significance, however aerobic metabolism continues with increasing oxygen uptake in a positive linear relationship to exercise intensity. At this stage the energy demands of the working tissues exceed the energy provided by aerobic metabolism. A further tissue oxygen deficit is added to the initial oxygen deficit when oxygen need in tissues is higher than its input (Astrand and Rodahl 1977). Therefore in spite of the increasing oxygen uptake the contribution of anaerobic energy replenishment and thus the total energy demand of the exercise increases exponentially to exercise intensity. The contribution of anaerobic metabolism (\% E aner.) during exercise at $50 \%$ and $70 \%$ of $\mathrm{V}_{\max }$ is thus $18.6 \%$ and $29.5 \%$ of the total exercise energy balance. It is possible to assume that during the exponential dependence of $\% \mathrm{E}$ anaer. on exercise intensity, the increasing contribution of anaerobic energy at exercise levels above $70 \% \mathrm{~V}_{\max }$ should be even more dramatic in saddle horses. Unfortunately, the construction of our respiratory mask, which is based on the registration of tidal volume as a measure of the pressure changes inside the mask does not allow measurement at higher exercise intensities.

It would be more interesting and objective to determine the contribution of anaerobic metabolism not only at higher exercise intensities, but also in relation to $\mathrm{VO}_{2 \text { max. }}$ In this way it should be possible to assess simultaneously the aerobic and the anaerobic capacity of the horse and its fitness. This is only possible using stepped exercise tests on a treadmill. Rose et al. (1988) determined maximal $\mathrm{O}_{2}$ uptake $\left(\mathrm{VO}_{2 \max }\right)$, maximal $\mathrm{O}_{2}$ deficit, and $\mathrm{O}_{2}$ debt in the Thoroughbred racehorses exercising on an inclined treadmill and through $60 \mathrm{~min}$ of 
recovery in this way. The oxygen uptake vs. speed relationship was linear up to $10 \mathrm{~m} / \mathrm{s}$ and the oxygen debt was approximately two to three times more than that in humans.

Thoroughbred horses have a high aerobic capacity, approximately twice that of elite human athletes. Whereas the aerobic capacity of horses can be accurately measured, there have been no measurements of anaerobic capacity made. Medbo et al. (1988) presented a method for quantifying the anaerobic capacity based on determination of the maximal accumulated $\mathrm{O}_{2}$ deficit (MAOD) in human athletes. Eaton et al. (1995) tried to determine whether maximal accumulated $\mathrm{O}_{2}$ deficit could be measured in horses and used as an estimate of anaerobic capacity, as in human athletes. The MAOD test was performed with a treadmill accelerated rapidly from $1.5 \mathrm{~m} / \mathrm{s}$ to the calculated speed 11-14 m/s. The proportion of energy derived from aerobic and anaerobic sources was similar as in our study. The authors could not find a correlation between MAOD and maximal $\mathrm{VO}_{2}$.

The importance of assessing the contribution of anaerobic metabolism during exercise as a criterion of estimated anaerobic capacity becomes also evident from Table 1 and Fig. 3. It is apparent that increase of aerobic energy utilisation $(\mathrm{E})$ at $70 \% \mathrm{~V}_{\max }$ in comparison to the standing value was 27 times greater and in comparison to exercise at the walk $\left(15 \% \mathrm{~V}_{\max }\right)$ it was only 5.5 times greater. Compared to walking exercise, the anaerobic energy utilisation (RD-E) increased 7 fold at $30 \% \mathrm{~V}_{\text {max }}$ (trot), 80fold at $50 \% \mathrm{~V}_{\max }$ (canter), and finally more than 200 fold at $70 \% \mathrm{~V}_{\max }$ (gallop). This illustrates that the contribution of anaerobic metabolism in increasing exercise intensities in the range 15 to $70 \% \mathrm{~V}_{\max }$ is roughly 40 times larger than that of the aerobic metabolic processes. Moreover the anaerobic mechanisms have a quicker response time. This state could be due to both a) the later adjustment of cardiorespiratory functions to oxygen need of working tissues during the first moment of increased workload, but also b) the varying velocities and complexities of the metabolic processes during anaerobic metabolism or oxidative phosphorylation, i.e. the anaerobic glycolysis is a simple and faster but less efficient process than oxidative phosphorylation.

Post-exercise oxygen uptake appears a suitable measure for the major part of the oxygen debt (relative oxygen debt) and could be considered as an indicator of anaerobically released energy. For this reason it may also be an indicator of the anaerobic capacity of the horse at a standard or maximal exercise.

\section{Odhad spotřeby kyslíku a výdeje energie u koní při zátěži v terénních podmínkách}

Hlavním cílem této studie bylo zhodnotit podíl aerobní a anaerobní úhrady energie na celkovém energetickém výdeji u teplokrevných koní při zátěži v terénních podmínkách. Byla stanovena spotřeba kyslíku $\left(\mathrm{VO}_{2}\right)$ u 12 jezdeckých koní v klidu, kroku, klusu a pomalém cvalu a u 6 koní v rychlém cvalu. Během 10 min po každé zátěži byl měřen relativní kyslíkový dluh $\left(\mathrm{RD}-\mathrm{VO}_{2}\right)$. Koně byli podrobeni pohybové zátěži s jezdci v rychlostech odpovídajícím 15, 30, 50 a 70\% jejich individuální maximální rychlosti $\left(\mathrm{V}_{\max }\right)$ na distancích $3000 \mathrm{~m} \mathrm{v}$ kroku, klusu a pomalém cvalu a $1500 \mathrm{~m}$ v rychlém cvalu. Byl studován vztah rychlosti $\mathrm{k} \mathrm{VO}_{2}, \mathrm{RD}-\mathrm{VO}_{2} \mathrm{~m}$ a výdeji energie (J.kg.min $\left.{ }^{-1}\right)$ stanovené pomocí kalorického ekvivalentu při naměřeném respiračním kvocientu (RQ), stejně jako podíl anaerobně uvolněné energie (\% E anaer.) k celkovému energetickému výdeji.

Byl nalezen lineární vztah mezi rychlostí a aerobně energetickým výdejem (E) a kvadratická závislost mezi rychlostí a anaerobně uvolněnou energií (RD-E) a celkovým výdejem energie (TE). Podíl \%E anaer. byl $1.21 \pm 0.40$ při rychlosti $15 \% \mathrm{~V}_{\max }, 3.40 \pm 0.38$ při $30 \% \mathrm{~V}_{\max }, 18.58 \pm 2.05$ při $50 \% \mathrm{~V}_{\max }$, a $29.47 \pm 1.17$ při $70 \% \mathrm{~V}_{\max }$.

Pozátěžový př́ijem kyslíku se jeví jako vhodné měřítko pro velkou část kyslíkového dluhu (relativní kyslíkový dluh) a může být považován jako indikátor anaerobně uvolněné energie. $\mathrm{Z}$ tohoto důvodu může být i indikátorem anaerobní kapacity koně při standardní nebo maximální zátěži. 


\section{Acknowledgements}

This work was supported by the research project of the Czech Ministry of Education No CEZ: J 16/98: 161700002

References

ASTRAND, P. O., RODAHL, K. 1977: Textbook of Work Physiology. $2^{\text {nd }}$ ed., McGraw-Hill Book Co., New York, $681 \mathrm{p}$.

CASTEJON, F., RUBIO, D., TOVAR, P., VINUESA, M., RIBER, C. 1994: A comparative study of aerobic capacity and fitness in three different horse breeds (Andalusian, Arabian and Anglo-Arabian). Zbl. Vet. Med. A 41: 645 - 652

EATON, M.D., EVANS, D. L., HODGSON, D. R., ROSE, R. J. 1995: Maximal accumulated oxygen deficit in Thoroughbred horses. J. Appl. Physiol. 78: 1564 - 1568

EATON, M. D., EVANS, D. L., HODGSON, D. R., ROSE, R. J. 1999: Effects of low- and moderate-intensity training on metabolic responses to exercise in Thoroughbreds. Equine Vet. J. Suppl. 30: 521 - 527

GOTLIEB-VEDI, M., PERSSON, S., ERICKSON, H., KORBUTIAK, E. 1995: Cardiovascular, respiratory and metabolic effects of interval training at VLa4. Zbl. Vet. Med. A 42: 165 - 175

HANÁK, J. 1987: Studium dynamiky metabolických procesů u sportovních a dostihových koní. DrSc. Thesis. Univ. Vet. Sci., Brno, 360 p.

HARKINS, J. D., BEADLE, R. E., KAMERLING, S. G. 1993: The correlation of running ability and physiological variables in Thoroughbred racehorses. Equine Vet. J. 25: 53 - 60

KARLSEN, G. G., NADALJAK, E. A. 1972: Legočnoe dychanie i gazoenergetičeskij obmen u verchovych lošadej $\mathrm{v}$ pokoe i při trenirovočnych rabotach pod sedlom. In: Naučnye trudy: Trenirovka rysistych i verchovych lošadej, Moskovskij rabočij, Moskva, pp. 61 - 68

KNUTTIGEN, H. G. 1970: Oxygen debt after submaximal physical exercise. J. Appl. Physiol. 29: 651 - 657

MEDBO, J.I., MOHN, A.C., TABATA, I., BAHR, R., VAAGE, O., SEJERSTED, O.M. 1988: Aerobic capacity determined by maximal accumulated $\mathrm{O}_{2}$ deficit. J. Appl. Physiol. 64: 50 - 60

MISUMI, K., HIRAKAWA, A., SAKAMOTO, H., SHIMIZU, R. 1994: Principal component analysis, using the measurements during running and swimming test, in Thoroughbred horses. J. Vet, Med, Sci. 56: 1075 - 1080

MUNOZ, A., SANTISEBAN, R., RUBIO, M. D., VIVO, R., AGUERA, E. I., ESCRIBANO, B. M., CASTEJON, F. M. 1997: The use of functional indexes to evaluate fitness in Andalusian horses. J. Med. Vet. Sci. 59: 747 752

PERSSON, S. G. B. 1983: Evaluation of exercise tolerance and fitness in the performance horse. In: Snow, D. H., Persson, S. G. B., Rose, J. R.: Equine Exercise Physiology, Burlington Press, Cambridge, pp. 441 - 457

PERSSON, S. G. B., ESSEN-GUSTAVSSON, B., LINDHOLM, A., McMIKEN, D. F., THORNTON, J. R. 1983 : Cardiorespiratory and metabolic effects of training of Standardbred yearlings. In: Snow, D. H., Persson, S. G. B., Rose, J. R.: Equine Exercise Physiology, Burlington Press, Cambridge, pp. 458 - 469

PERSSON, S. G. 1997: Heart rate and blood lactate responses to submaximal treadmill exercise in the normally performing Standardbred trotters - age and sex variations and predictability from the total red blood cell volume. Zbl. Vet. Med. A 44: 125 - 132

POSO, A. R., ESSEN-GUSTAVSSON, B., PERSSON, S. G. 1993: Metabolic response to standardised exercise test in Standardbred trotters with red cell hypervolemia. Equine Vet. J. 25: 527 - 531

ROSE, R. J., HODGSON, D. R., KELSO, T. B., McCUTCHEON, L. J., REID, T. A., BAYLY, W. M., GOLLNICK, P. D. 1988: Maximum $\mathrm{O}_{2}$ uptake, $\mathrm{O}_{2}$ debt and deficit, and muscle metabolites in Thoroughbred horses. J. Appl. Physiol. 64: 781 - 788

ROSE, R. J., HENDRICKSON, D. K., KNIGHT, P. K. 1990: Clinical exercise testing in the normal Thoroughbred racehorse. Austr. Vet. J. 67: 345 - 348 